\title{
Corrigendum
}

\section{Peptide nucleic acid delivery to human mitochondria}

PF Chinnery, RW Taylor, K Diekert, R Lill, DM Turnbull and RN Lightowlers

Gene Therapy 1999; 6: 1919-1928

In the above article, the authors inadvertently used the incorrect extinction coefficient of $8900 \mathrm{M}^{-1} \mathrm{~cm}^{-1}$ for calculating concentrations of PNAs and their conjugates at 260 nm. Measurements should have been made using 97900 $\mathrm{M}^{-1} \mathrm{~cm}^{-1}$. Consequently, all concentrations are effectively 11-fold more dilute than reported. 